\title{
The role of cytokines and adhesion molecules in maternal recognition and establishment of pregnancy in pig
}

\author{
M. Bogacki, M. Wasielak and A. Zięcik ${ }^{1}$ \\ Institute of Animal Reproduction and Food Research, \\ Polish Academy of Sciences \\ 10-747 Olsztyn, Tuwima 10, Poland
}

(Received 15 June 2005; accepted 17 October 2005)

\begin{abstract}
Oestrogen synthesis and release by day 11 conceptus is known as the main signal for the maternal recognition of pregnancy in the pig. The maternal recognition and subsequent establishment of pregnancy require a complex network of interactions between embryo and uterus. Both embryo and uterus secrete various signaling molecules, all of which are necessary for the initiation of the foetomaternal relationship. Many of the events during peri-implantation period have an inflammatory character, therefore are accompanied by increased amounts of cytokines. Porcine conceptus expression of interleukins and other cytokines have been reported. Pregnancy-specific endometrial expression of leukaemia inhibitory factor (LIF) is initiated during the conceptus elongation and can affect conceptus development. Moreover, enormous antiviral activity, coordinated with increased interferons secretion, has been detected at the time of blastocyst implantation in pig. This prolonged pre-receptive period is followed by implantation which results in conceptus attachment to the uterine epithelium. Adhesion to the uterine epithelium is controled mainly by integrins but also other adhesion molecules such as Muc1, Muc 4 or osteoponin, have been implicated in the porcine implantation cascade. Since there is increasing amount of evidence that cytokines and adhesion molecules are crucial for interactions between conceptus and uterus, we decided to present the discussion on their role in recognition and establishment of pregnancy in the pig. This review may help to understand better mechanisms occurring in the peri-implantation period in pigs.
\end{abstract}

KEY WORDS: pig, pregnancy, cytokines, adhesion molecules

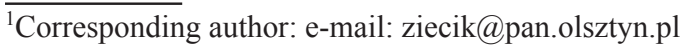




\section{INTRODUCTION}

The knowledge on the mechanisms and factors regulating maternal recognition and establishment of pregnancy in mammals has significantly increased through past decades, however, much remains to be investigated in the pig.

Recognition and subsequent establishment of pregnancy seem to be challenging processes promoted by a complex network of many signaling molecules. All these interactions are only initiated when the embryo reaches the blastocyst stage, and the uterus, through steroid hormone-dependent changes, attains the receptive stage (Dey, 2004).

The implantation process is currently considered as the most important limiting factor for the establishment of viable pregnancy. It has been postulated that successful implantation in mammals is highly coordinated process, requiring maternal recognition of pregnancy, apposition, adhesion and trophoblast invasion into the luminal epithelium of the endometrium (Rice and Chad, 1998). Implantation in the pig follows a long preattachment period that includes migration and spacing of embryos within the uterus and the rapid alternation in embryo morphology, in which the spherical blastocyst elongates to a form of filamentous thread-like conceptus (Bazer, 1975; Geisert and Yelich, 1997; Burghardt et al., 2002). After the rapid morphological rearrangement of the trophoblast, on approximately day 12 of pregnanacy, porcine conceptuses initiate attachment to the uterine luminal surface. This transformation in structural morphology coincides with elevated oestrogen synthesis and release by the conceptus, which is required for the recognition of pregnancy in pigs (Ross et al., 2003).

All the events described above are accompanied by significant changes in the tissue concentration of various hormones, growth factors, enzymes, cytokines and adhesion molecules, all of which may be crucial for initiation of the foetomaternal relationship (Rice and Chad, 1998; Saito, 2002). It is postulated that cytokines and growth factors may serve as the link in the regulation of adhesion molecules that provide the physical contact between apical aspects of conceptus trophoectoderm and maternal luminal epithelium that leads to formation of an epitheliochorial placenta (Simon et al., 1998). Since, there is growing interest in the issue on the role of cytokines and adhesion molecules in events leading to maternal recognition and establishment of pregnancy in pigs we decided to summarize the present state of knowledge in this review.

\section{CYTOKINES IN PERI-IMLANTATION PERIOD IN PIG}

Cytokines are low molecular weight proteins which participate in several immunomodulatory mechanisms but are also known to be closely involved in 
reproduction, i. e. ovarian follicular development, maintenance of the corpus luteum, trophoblast growth and differentiation and supposedly in implantation (Hunt and Roby, 1994; Savino and Dardenne, 1995). The local presence of a sufficient amount of cytokines seems to be decisive for embryonic survival (Nasu et al., 1999). Many of the endometrial responses evoked by the porcine conceptuses during trophoblastic elongation and subsequent adhesion to the uterine surface resemble IL-mediated acute-phase responses induced during inflammation of the tissue (Geisert and Yelich, 1997). Cytokines signaling might be also important for modulation of immune responses during the process of maternal recognition of pregnancy and implantation.

\section{Interleukin-1 $\beta$}

Interleukin- $1 \beta(\mathrm{IL}-1 \beta)$ is known as a one of the critical inflammatory cytokines involved in many physiological processes. It mediates immune responses, metabolism of pro-inflammatory reactions and pathological processes (Dinarello, 1991). In the cascade of immune responses, IL-1 $\beta$ is derived mainly from antigen presenting cells such as monocytes and macrophages. IL-1 $\beta$ together with other cytokines such as IL-2, IL-4, IL-6 and interferon- $\gamma($ INF- $\gamma$ ) stimulates immune cells to increased cytokines production (Dinarello, 1991). In pigs IL-1 $\beta$ has been characterized in synovial fluid and leukocytes and its function in the immune and non-immune systems seems to be similar to IL-1 $\beta$ function in other species (Saklatvala et al., 1985).

It is possible that IL-1 $\beta$ plays an important role in the trophoblastic elongation and in the cross-talk between the embryo and endometrium. It has been also suggested that IL-1 $\beta$ is the initiator of placental-uterine interfacing needed for the establishment of pregnancy (Ross et al., 2003).

Gene for IL-1 $\beta$ was identified and differentially expressed during the process of rapid trophoblastic elongation. Tuo et al. (1996) demonstrated high levels of IL-1 $\beta$ mRNA in days 11-13 conceptuses. IL-1 $\beta$ protein was detected in conceptuses on days 11-14 and its biological activity was demonstrated on days 11 and 12 conceptus homogenates. Following the initial sharp increase in IL-1 $\beta$ on day 12 conceptus, gene expression was reduced more than 2000 times by day 15 of gestation. Low levels of IL- $1 \beta$ m RNA were detected by Northern blot analysis in endometrium and myometrium on day 15 of pregnancy. Ross et al. (2003) demonstrated the presence of IL-1 $\beta$ in the uterine lumen during the time of conceptus elongation and maternal recognition of pregnancy on day 12 of gestation. Also uterine lumen content of IL- $1 \beta$ was increased during initiation of rapid trophoblastic elongation. Similarly, IL-1 $\beta$ protein availability in the uterine lumen was declining on day 15 but returned to pre-elongation concentration by 
day 18 of gestation. The production of IL- $1 \beta$ by peri-implantation pig conceptuses was temporarily associated with maternal recognition of pregnancy. It suggests that IL-1 $\beta$ of conceptus origin may be important for conceptus development and establishment of pregnancy. Absence of IL-1 $\beta$ protein in the uterine lumen on day 12 and 15 of oestrous cycle with the increase of conceptus IL- $1 \beta$ gene expression detected during trophoblastic elongation suggest that IL-1 $\beta$ in the uterine lumen originates from peri-implantation conceptuses.

This pattern of IL-1 $\beta$ expression and protein secretion is associated with IL$1 \beta$ receptor type 1 (IL-1R1) and IL-1 receptor accessory protein (IL-1RAP) gene expression in elongated conceptuses (day 12-15) and endometrium from pregnant gilts on day 12 of gestation. Although IL-1 $\beta$ may function through multiple receptors, the IL-1R1 and IL-1RAP are needed for initiation of biological response of IL1- $\beta$ (Cullian et al., 1998). Conceptuses expression for IL-1R1 and IL-1RAP is grater in filamentous conceptuses compared to earlier morphological stages and tends to decline in day 18 conceptuses (Ross et al., 2003). Increase in IL-1R1 expression may be in part due to the up-regulation of its own receptor by IL- $\beta$ by itself as it was postulated in human (Simon et al., 1994). Endometrial IL-1R1 and IL-1RAP gene expression decrease following conceptus trophoblastic elongation and initial apposition to uterine apical surface on day 12 of gestation, whereas conceptus IL1R1 and IL-1RAP gene expression continued to be elevated following conceptus expansion. Along with IL-1R1 and IL-1RAP gene expression, conceptus IL1- $\beta$ expression and content of IL-1 $\beta$ protein in the uterine lumen likely induces biological action in both endometrium and conceptus (Ross et al., 2003).

Since IL-1 $\beta$ is a potent stimulator of aromatase activity (Nestler, 1993) and IL-1 $\beta$ gene expression in conceptuses and protein secretion to uterine lumen is correlated with the conceptuses $\mathrm{E} 2$ production during the time of rapid trophoblastic elongation, there is suggestion that IL-1 $\beta$ in cooperation with E2 may be involved in process of conceptus elongation (Ross et al., 2003). However, conceptus IL$1 R 1$ and IL-1RAP gene expression and IL1- $\beta$ secretion to uterine lumen through day 15 suggest that IL-1 $\beta$ plays also other role in the implantation process after conceptus elongation (Ross et al., 2003).

IL-1 $\beta$ may act as an inducer of phospholipase A2 to regulate the release of arachidonic acid from the phospholipids bilayer, allowing membrane fluidity necessary for remodeling of the trophoectoderm during elongation and its conversion to prostaglandins needed for placental attachment during the establishment of pregnancy (Davis and Blair, 1993; Geisert and Yelish, 1997).

IL-1 $\beta$ induces cyclooxygenase-2 (COX-2) gene expression in cultured human endometrial stromal cells (Huang et al., 1998). However, preliminary data of Blitek and Zięcik (unpublished) did not confirm IL-1 $\beta$ stimulatory effect on COX2 in pigs but they found that porcine endometrial stromal cells treated with IL-1 $\beta$ 
secreted over two times more both prostaglandins E2 and F2 $\alpha$. While conceptus production of prostaglandins may not be necessary for inducing trophoblast elongation (Geisert et al., 1986), prostaglandins may be essential for placental attachment (Kraeling et al., 1985) and play role in the protection of corpus luteum against luteolysis.

\section{Leukaemia inhibitory factor, interleukin-6, tumor necrosis factor- $\alpha$}

The effects of leukaemia inhibitory factor (LIF) in many physiological systems include proliferation, differentiation and cell survival, all of which are associated with blastocyst development and implantation (Vogiagis and Salamonsen, 1999). LIF actions can be mimicked by related cytokines, in particular interleukin 6 (IL6). LIF and IL-6 serve also as embryo-maternal signaling molecules which are present within the uterine luminal environment.

Endometrial expression of pregnancy-specific leukaemia inhibitory factor (LIF) is initiated during the period of conceptus elongation and can affect conceptus development because preimplantation porcine conceptuses express LIF receptor (Anaegon et al., 1994; Modric et al., 2000). Moreover, high antiviral activity, associated with the interferons secretion is observed at the time of blastocyst implantation in pigs (Cross and Roberts, 1989). The interaction of endometrial LIF with the conceptus derived factors, is thought to be most important for successful implantation and this may contribute to the local control of trophoblast and endometrial proliferation (Schafer-Somi, 2003). It was found that LIF may control trophoblast and endometrium proliferation via induction of beta- $2 \mathrm{~m}$ microglobulin (beta-2m) mRNA (Modric et al., 2000). Beta-2m is present as a subunit of histocompatibility antigens on the cell surfaces and known as an in vitro mitogen (Berggard, 1976; Modric et al., 2000).

Presence of IL-6 mRNA in elongated preimplantation conceptuses from pigs on day 13-21 suggested that IL-6 may provoke early maternal reaction that is necessary for maintenance of pregnancy (Anegon et al., 1994; Modric et al., 2000). Rapid development of spherical conceptuses to the filamentous stage in days 11-12 was accompanied by transiently increased IL-6 expression associated with increase in leukaemia inhibitory factor receptor (LIFR) mRNA expression. Interleukin-6 activity was detected in uterine lumen fluid in early pregnancy but also during oestrus cycle. LIF and IL-6 mRNA were also detected in day 11 endometrium (Anageon et al., 1994) and also high amounts of LIF, LIFR-beta and IL-6 mRNAs in both the endometrium and placenta were evident at the postimplantation stages (Modric et al., 2000).

Placental attachment in the pig invokes an acute-phase inflammatory response (Geisert and Yelich, 1997). At this time, the formation of conceptus-uterine 
extracellular matrix is essential. Tumor necrosis factor stimulated gene (TSG)-6 is induced not only by tumor necrosis factor (TNF- $\alpha$ ) but also by IL-1 $\beta$ (Lee et al., 1992) and prostaglandin E2 (PGE) (Fujimoto et al., 2002). Beside the antiinflamatory action (Wisniewski et al., 1996) TSG-6, is thought to be involved in cumulus-oocyte matrix formation in mice because of its ability to bind to and stabilize the covalent bond between the hyaluronic acid and the heavy chain of inter- $\alpha$-trypsin inhibitor (Richards et al., 2002). Inter- $\alpha$-trypsin inhibitor has been reported on the porcine endometrium and hypothesized to assist in the attachment of the conceptus to the uterine surface by stabilizing the uterine ephitelial surface glycocalyx (Geisert and Yelich, 1997). It is possible that conceptus IL-1 $\beta$ production may initially stimulate TSG-6 production during conceptus elongation and induce COX-2 expression for continued stimulation of TSG-6 through placental PGE 2 release. Conceptus and endometrial expression of TSG-6 during establishment of pregnancy needs further investigations in pigs.

According to Wuttke et al. (1998), TNF- $\alpha$ play role in initiation of luteolysis rather than in early recognition of pregnancy. The source of TNF- $\alpha$ could be lymphocytes and macrophages that are recruited into the corpus luteum destined to regress (Pate and Kayes, 2001). Infiltration of macrophages into aging CL in pigs appears to release TNF- $\alpha$ in response to $\mathrm{PGF}_{2 \alpha}$ and TNF seems to inhibit luteal steroidogenesis. Administration of $\mathrm{PGF}_{2 \alpha}$ into porcine corpus luteum resulted in massive invasion of macrophages into luteal tissue (Hehnke et al., 1990). This recruitment of immune cells does not occur at the similar time at early pregnancy (Lobel and Levy, 1968; Bogavandos et al., 1990). The changed ratio of PGF : $\mathrm{PGE}_{2}$ during peri-implantation period of pregnancy can abort an inhibition of TNF- $\alpha$ on luteal steroidogenesis and protect the CL against luteolysis.

\section{Interferons}

Interferons (IFNs) represent a group of proteins that were initially related to their ability to protect cells against viral infections. Recently, IFNs are defined as proteins synthesized by the cells after exposure to a variety of stimuli and able to exert a broad spectrum of biological actions (Ljizermans and Marquet, 1989).

Based on the antigenic, structural, biochemical and biological criteria, IFNs have been divided into two main types. Type I IFNs $(\alpha, \beta, \tau, \delta, \omega)$ acting through the same Type I IFNs receptor on the susceptible cells and Type II IFNs including an unique member- IFN- $\gamma$ that has a multipotential role in the immune reactions (Ljizermans and Marquet, 1989). The role of these embryonic INFs is not known but pressumably in the pig these interferons may participate in the remodeling of the uterine endometrial epithelium, as a prerequisite for implantation and establishment of pregnancy (Cenic et al., 2003). 
Interferone- $\tau$ was identified as the main embryonic signal in ruminants but has not been found so far in pigs. Between days 12 and 20 of pregnancy, the trophoectoderm of the porcine conceptus secretes two species of interferones: INF- $\gamma$, which is produced in substantial amounts with peak secretion at days 15-16. Other data indicated that pig conceptuses secrete both IFN- $\alpha$ and IFN- $\gamma$ between days 15-21 of gestation (Bazer, 1992). Large IFN- $\gamma$ production by the preimplantation conceptuses appears to be unique for the pig (La Bonnardiere, 1993). Mechanism by which expression of tophoblastic INF- $\gamma$ is regulated remains unknown but the site of production was immunolocalized in the extraembrionic trophoectoderm, the external monolayer of trophoblast (Lefevre et al., 1990).

Potentially, IFN- $\gamma$ increases the expression of several proteins and in this way may promote cell adherence during the implantation process (Ozaki et al., 1999). IFN $-\gamma$ produced by pig conceptus might be associated with endometrial defense against non viral antigens (Shafer-Somi, 2003) and this possible role is discussed very detailed by Cencic and La Bonnardiere (2002). Also high antiviral activity has been found at the time of blastocyst implantation (Cross and Roberts, 1989). Literature data demonstarate that, unlike INF- $\tau$ in ruminants, porcine IFN- $\gamma$ does not contribute to the antiluteolytic effect that help to maintain the corpus luteum function. Although oestrogens appear to be main or exclusive factor of maternal reconition of pregnancy in pigs, possible synergic role of INFs may be considered.

TABLE 1

Days of expression of endometrial and embryonic cytokines and adhesion molecules associated with implantation process in the pig

\begin{tabular}{lcc}
\hline \multirow{2}{*}{ Factors } & \multicolumn{2}{c}{ Days of pregnancy } \\
\cline { 2 - 3 } & conceptus & endometrium \\
\hline Cytokines & & \\
oestrogens & $11-22$ & \\
oestrogens receptors & 12 & \\
IL-1 $\beta$ & $10-18$ & \\
IL-1 $\beta$-receptor & $8-18$ & \\
IL-6 & $13-21$ & \\
LIF & & \\
LIF receptor & $11-21$ & \\
IFN- $\alpha$ & $15-21$ & \\
IFN- $\gamma$ & $12-20$ & 11 \\
INF- $\delta$ & $12-21$ & 4 \\
Adhesion molecules & & $5-15$ \\
integrins & & $11-21$ \\
MUC-1 & & \\
MuC-4 & & \\
OPN & & \\
\hline
\end{tabular}


IFN- $\delta$ is coexpressed with IFN- $\gamma$ by the pig trophectoderm during preimplantation period but in much lower amounts than IFN- $\gamma$. Like INF- $\gamma$, IFN- $\delta$ is secreted from apical side of the trophoblast monolayer but its secretion is distributed evenly through the cytoplasm, suggesting a different secretory pathway (Lefevre et al., 1998).

IFN- $\gamma$, IFN $\delta$ and INF- $\alpha$ can be considered as trophoblastic interferons and it seems that they play synergic and supportive role to oestrogens rather than apparent role in the maternal recognition of pregnancy.

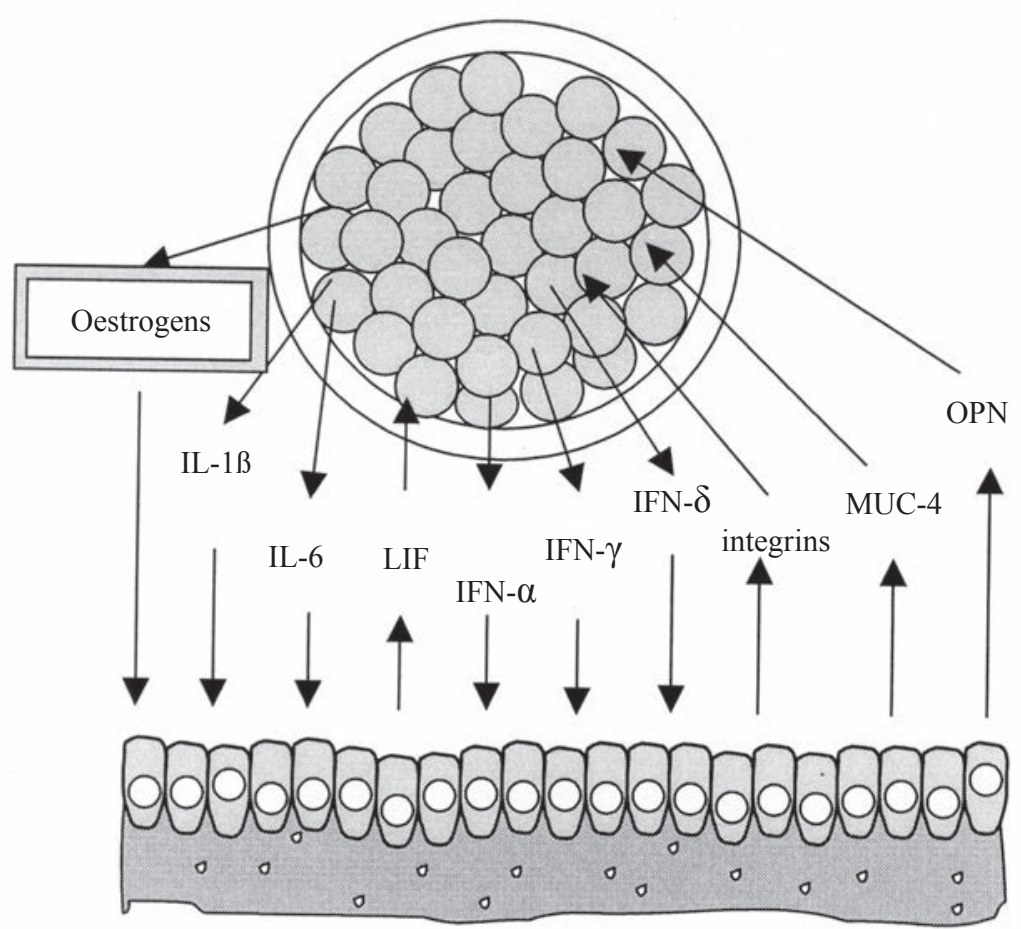

Figure 1. Schematic presentation of the cytokines and adhesion molecules cross-talk between conceptus and endometium during the peri-implantation period in pigs

\section{ADHESION MOLECULES}

The structural and functional alterations of uterine epithelial cells that permit the apical-apical union of conceptus and uterine epithelium are complex and are likely to involve many different adhesion molecules with distinct but inter-related functions. A number of changes in the molecular composition at the apical surface 
of uterine epithelial cells associated with the transition from the pre-receptive to the receptive state in the pig uterus are reviewed. Molecules that function in the adhesion cascade resulting in implantation are represented by a variety of adhesion systems (Burghardt et al., 1997).

Attachment of the placenta to the uterus in pigs involves extracellularinteractions between the expanding trophoblastic membrane and the thick glycocalyx present on the uterine epithelial microvilli.

Integrins are probably the dominant adhesion molecules because their capacity to mediate adhesion is linked to their activation by engaging other surface molecules that have been implicated in the cascade of implantation (Bowen et al., 1996). They comprise a large family of transmembrane heterodimeric glycoprotein receptors that are associated with the cytoskeleton and signaling proteins (Giancotti et al., 1999). Integrin receptors, composed of $\beta$ subunits, participate in bidirectional signaling involving both "outside-in" (i.e. ligand activation at the cell surface to modify cytoskeletal organization, intracellular signaling, and gene expression) as well as "inside- out" (i.e. cytoplasmic domain transduction of intracellular signals to regulate ligand binding affinity) pathways (Hynes, 1987). In the porcine endometrium and conceptus several integrin subunits $(\alpha v, \alpha 4, \alpha 5, \beta 1, \beta 3$, and $\beta 5)$ are expressed on the apical surface of both endometrial laminar epithelium (LE) and conceptus trophectoderm (Bowen et al., 1996; Garlow et al., 2002). Uterine epithelial expression of integrin subunits $\alpha 4, \alpha 5$, and $\beta 1$ increases during the period of maternal recognition on day 10-15 of pregnancy (Bowen et al., 1996). Extracellular matrix components, fibronectin and vitronectin were present in trophectoderm and vitronectin was detected on uterine epithelium. The $\alpha 4$, $\alpha 5, \alpha v, \beta 1$, and $\beta 3$ integrin subunits, fibronectn and vitronectin are localized on attachment sites between uterine epithelial cells and trophectoderm on day 12-15 of pregnancy (Bowen et al., 1996). The integrin subunits potentially give rise to the integrin corresponding receptors at the maternal-foetal interface during pregnancy and may function as a part of an adhesion cascade that serves to generate both stable adhesion between apposing epithelial surfaces and activation of outside-in signal transduction (Burghardt et al., 1997).

Muc-1 is a large (200-1000-kDa), heavily glycosylated integral transmembrane glycoprotein. Intense Muc-1 staining was detected on apical uterine epithelium on day 0 and day 4, but decreased to nondetectable levels by day 10 in both cyclic and pregnant gilts. The staining pattern for day 4 of the oestrous cycle was identical to that for ovariectomized gilts receiving either vehicle or E2, whereas ovariectomized gilts treated with P4 or E2 with P4 did not exhibit Muc-1 staining. These results suggest that $\mathrm{P} 4$, even in the presence of $\mathrm{E} 2$, mediates events that suppress expression of Muc-1 protein. A pattern of Muc-1 expression detected in pigs is similar to that reported for rodents (Bowen et al., 1996; Burghardt et al., 
1997), in which there is decreased Muc-1 mRNA and protein expression during the implantation window (Bowen et al., 1996). Thus Muc-1 expression may determine the prereceptive, nonadhesive state of the uterine epithelium before implantation in pigs (Bowen et al., 1997)

Muc-4 (sialomucin complex) immunostaining increases on the surface and glandular epithelia between days 5 and 10 of oestrous cycle. Immunostaining continued to increase on day 12 with the greatest intensity of uterine Muc-4 immunostaining detected on day 15 of the oestrous cycle and early pregnancy. Endometrial Muc-4 expression in cyclic gilts decreased dramatically during early proestrous but continued to remain abundant on the surface and glandular epithelium of pregnant gilts during the period of conceptus attachment to the uterine surface (Ferrell et al., 2003).

Kallikrein-kininogen-kinin system. Following rapid trophoblast elongation on day 12 of pregnancy there is an increase in tissue kallikrein activity. In comparison to cyclic gilts, endometrial L-kininogen gene expression increased fourfold on days 15 and 18 of pregnancy. Concentration of bradykinin in uterine flushings was a 5- to 10-fold increased in pregnant uterine flushings on days 12-18 of pregnancy compared with the oestrous cycle. Endometrial bradykinin beta (2) receptor gene expression was greatest on days $0,12,15$, and 18 of the oestrous cycle and pregnancy as gene expression decreased almost 6-fold on days 5 and 10 . These data suggest that the kallikrein-kinin system is biologically active during establishment of pregnancy in the pig (Vonnahme et al., 2004)

Osteoponin (OPN) is a highly phosphorylated acidic glycoprotein that stimulates cell to cell adhesion, increases cell-extracellular matrix communication, and promotes cell migration (see reviews in Denhardt and Guo, 1993; Sodek et al., 2000).

OPN mRNA is expressed by the pig uterine LE and glandular ephithelium (GE), but not by conceptus trophectoderm. OPN protein is present in the uterine lumen and localized on the uterine LE and GE , and conceptus trophectoderm. OPN binding to integrin receptors induces cytoplasmic reorganization and foetal adhesions to porcine uterine LE and conceptus trophectoderm cells in vitro.

Expression of OPN mRNA in pig uterus is barely detectable in LE on day 12 of pregnancy, increases in discrete regions of the LE by day 15, and is expressed maximally in all LE by day 20 of pregnancy. Although, OPN mRNA was not detected in conceptus trophectoderm, however OPN protein was found on trophectoderm on day 12-13 of pregnancy. OPN protein in the endometrium was higher on day 9 and between days 35-85 of pregnancy (Garlow et al., 2002).

Interestingly, OPN mRNA and protein expression pattern in the porcine uterus temporally and spatially corresponds with conceptus elongation, implantation, and placentation involving adhesion molecule-dependent remodeling of endometrium 
and trophectoderm. OPN therefore may mediate conceptus trophectoderm attachment, growth, and spreading on uterine LE.

\section{CONCLUSIONS}

The cytokines participate in the conceptus-uterine communication pathways and regulate the expression of endometrial adhesion molecules which determine the correct implantation and subsequent placentation to ensure the foeto-maternal well-being. Endometrial epithelium remains under the control of steroid hormones, particularly progesterone and thus, the control of cytokines by this steroid may be important. Since, both the maternal immune and endocrine systems are involved in the recognition of pregnancy and adhesion of the conceptus to the uterine epithelium, a new integrated approach to the conceptus-maternal interactions leading to recognition, establishment and successful maintenance of pregnancy in pig, is awaited.

\section{REFERENCES}

Anaegon I., Cuturi M.C., Godard A., Moreau M., Terqui M., Martinat-Botte F., Soulillou J.P., 1994. Presence of leukaemia inhibitory factor and interleukin-6 in porcine uterine secretions prior to conceptus attachement. Cytokine 6, 493-499

Bazer F.W., 1975. Uterine protein secretions: Relationship to development of the conceptus. J. Anim. Sci. 41, 1376-1382

Bazer F.W., 1992. Mediators of maternal recognition of pregnancy in mammals. Proc. Exp. Biol. Med. 199, 373-384

Berggard I., 1976. beta-2-Microglobulins: isolation, properties and distribution. Fed. Proc. 35, 1167-1170

Bogavandos P., Wiggins R.C., Kunkel S.L., Remick D.G., Keyes P.L., 1990. Tumor necrosis factor production and accumulation of inflammatory cells in the corpus luteum of pseudopregnancy and pregnancy in rabbits. Biol. Reprod. 42, 367-376

Bowen J.A., Bazer F.W., Burghardt R.C., 1996. Spatial and temporal analyses of integrin and Muc-1 expression in porcine uterine epithelium and trophectoderm in vivo. Biol. Reprod. 55, 10981106

Bowen J.A., Bazer F.W., Burghardt R.C., 1997. Spatial and temporal analyses of integrin and Muc-1 expression in porcine uterine epithelium and trophectoderm in vitro. Biol. Reprod. 56, 409-415

Burghardt R.C., Bowen J.A., Newton G.R., Bazer F.W., 1997. Extracellular matrix and the implantation cascade in pigs. J. Reprod. Fertil., Suppl. 52, 151-64

Burghardt R.C., Johnson G.A., Jaeger L.A., Ka H., Garlow J.E., Spencer T.E., Bazer F.W., 2002. Integrins and extracellular matrix proteins at the maternal-fetal interface in domestic animals. Cell Tiss. Org. 172, 202-217

Cencic A., Guillomot M., Koren S., La Bonnardiere C., 2003. Trophoblastic interferons: do they modulate uterine cellular markers at the time of conceptus attachment in the pig? Placenta 24, 862-869 
Cencic A., La Bonnardiere C., 2002. Trophoblastic interferon-gamma: current knowledge and possible role(s) in early pig pregnancy. Vet. Res. 33, 139-157

Cross J.C., Roberts R.M., 1989. Porcine conceptuses secrete an interferon during the preattachement period of early pregnancy. Biol. Reprod. 40, 1109-1118

Cullian F.B., Kwee L., Nunes P., Shuster D.J., Ju G., McIntyre K.W., Chizzonite R.A., Labow M.A., 1998. IL-1 receptor accessory protein is an essential component of the IL-1 receptor. J. Immunol. 161, 5614-5620

Davis D.L., Blair R.M., 1993. Studies of uterine secretions and products of primary cultures of endometrial cells in pigs. J. Reprod. Fertil., Suppl. 48, 143-155

Denhardt D.T., Guo X., 1993. Osteopontin: a protein with diverse functions. FASEB J. 7, 1475-1482

Dey S.K., 2004. Focus on implantation. Reproduction 128, 655-656

Dinarello C.A., 1991. Interleukin-1. In: A. Thomson (Editor). The Cytokine Handbook. Academic Press, San Diego, pp. 47-82

Ferrell A.D., Malayer J.R., Carraway K.L., Geisert R.D., 2003. Sialomucin complex (Muc4) expression in porcine endometrium during the oestrous cycle and early pregnancy. Reprod. Domest. Anim. 38, 63-65

Fujimoto T., Savani R.C., Watari M., Day J., Strauss J.F., 2002. Induction of the hyaluronic acidbinding protein, tumor necrosis factor-stimulated gene-6, in cervical smooth muscle cells by tumor necrosis factor- $\alpha$ and prostaglandin E2. Amer. J. Pathol. 160, 1495-1502

Garlow J.E., Ka H., Johnson G.A., Burghardt R.C., Jaeger L.A., Bazer F.W., 2002. Analysis of osteopontin at the maternal-placental interface in pig. Biol. Reprod. 66, 718-25

Geisert R.D., Rasby R.J., Minton J.E., Wetteman R.P., 1986. Role of prostaglandins in development of porcine blastocysts. Prostaglandins 31, 191-204

Geisert R.D., Yelich J.V., 1997. Regulation of conceptus development and attachement in pigs. J. Reprod. Fertil., Suppl. 52, 133-149

Giancotti F.G., Ruoslahti E., 1999. Integrin signaling. Science 285, 1028-1032

Hehnke K.E., Christenson L.K., Ford S.P., Taylor M., 1990. Macrophage infiltration into porcine corpus luteum during prostaglandin $\mathrm{F}_{2 \alpha}$ - induced luteolysis. Biol. Reprod. 50, 10-15

Huang J.C., Liu D.Y., Yadollah S., Wu K.V., Dawood M.Y., 1998. Interleukin-1 $\beta$ induces cyclooxygenase-2 gene expression in cultured endometrial stromal cells. J. Clin. Endocrinol. Metab. 83, 538-541

Hunt J.S., Roby K.F., 1994. Implantation factors. Clin. Obstet. Gynecol. 37, 635-645

Hynes R.O., 1987. Integrins: a family of cell surface receptors. Cell 48, 549-554

Kraeling R.R., Rampacek G.B., Forello N.A., 1985. Inhibition of pregnancy with indomethacin in mature gilts and prepubertal gilts induced to ovulate. Biol. Reprod. 32, 105-110

La Bonnardiere C., 1993. Nature and possible functions of interferons secreted by the preimplantation pig blastocyst. J. Reprod. Fertil., Suppl. 48, 157-170

Lee T.H., Wisniewski H.G., Vilcek J., 1992. A novel secretory tumor necrosis factor-inducible protein (TSG-6) is a member of the family of hyaluronate binding proteins, closely related to the adhesion receptor CD44. J. Cell Biol. 116, 545-557

Lefevre F., Guillomot M., D‘ Andrea S., Battegay S., La Bonnardiere C., 1998. Interferon-delta: the first member of a novel type I interferon family. Biochemie 80, 79-88

Lefevre F., Martinat-Botte F., Guillomont M., Zouari K., Charley B., La Bonnardiere C., 1990. Interferon-gamma gene and protein are spontaneously expressed by the porcine trophoectoderm early in gestation. Eur. J. Immunol. 20, 2485-2490

Ljzermans J.N.M., Marquet R.L., 1989. Interferon-gamma: a review. Immunobiology 179, 456-473

Lobel B.L., Levy E., 1968. Enzymatic correllates of development, secretory function and regression of follicles and corpora lutea in he bovine ovary. II. Formation, development and involution of 
corpora lutea. Act. Endocrinol. 59, Suppl. 132, 35-67

Modric T., Kowalski A.A., Green M.L., Simmen F.A., 2000. Pregnancy-dependent expression of leukaemia inhibitory factor (LIF), LIF receptor- $\beta$ and interleukin 6 (IL-6) messenger ribonucleic acids in the porcine female reproductive tract. Placenta 21, 345-353

Nasu K., Narahara H., Matsui N., Kawano Y., Tanaka Y., Miyakawa I., 1999. Platelet-activating factor stimulates cytokine production by human endometrial stromal cells. Mol. Hum. Reprod. $5,548-553$

Nestler J.E., 1993. Interleukin-1 stimulates the aromatase activity of human placental cytotrophoblasts. Endocrinology 132, 566-570

Ozaki H., Ishii K., Houriuchi H., Arai H., Kawamoto T., Okawa K., Iwamatsu A., Kita T., 1999. Cutting edge: Combined treatment of TNF- $\alpha$ and INF- $\gamma$ causes redistribution of junctional adhesion molecule in human endothelial cells. J. Immunol. 63, 553-557

Pate J.L., Keyes P.L., 2001. Immune cells in the corpus luteum: friends or foes? Reproduction 122, 663-676

Rice A., Chard T., 1998. Cytokines in implantation. Cytokine Growth Hormones Rev. 9, 287-296

Richards J.S., Russell D.1., Ochsner S., Espey L.L., 2002. Ovulation: new dimensions and new regulators of the inflammatory-like response. Annu. Rev. Physiol. 64, 69-92

Ross J.W., Malayer J.R., Ritchey J.W., Rodney D., Geisert D., 2002. Characterization of the interleukin-1 $\beta$ system during porcine trophoblastic elongation and early placental attachment. Biol. Reprod. 89, 1251-1259

Saito S., 2000. Cytokines network at the feto-maternal interface. J. Reprod. Immunol. 47, 87-103

Savino W., Dardenne M., 1995. Immune-neuroendocrinne interactions. Immunol. Today 16, 318-322

Schäfer-Somi S., 2003. Cytokines during early pregnancy of mammals: a review. Anim. Reprod. Sci. $75,73-94$

Simon C., Moreno C., Remohi J., Pellicer A., 1998. Cytokines and embryo implantation. J. Reprod. Immunol. 39, 117-131

Simon C., Piquette G.N., Frances A., El-Danasouri I., Irwin J.C., Polan M.L., 1994. The effect of interleukin-1 $\beta$ (IL-1 $\beta$ ) on the regulation of IL-1 receptor type I messenger ribonucleic acid and protein levels in cultured human endometrial stromal and glandular cells. J. Clin. Endocrinol. Metab. 78, 675-682

Skalatvala J., Sarsfield S.J., Townsed Y., 1985. Pig interleukin-1: purification of two immunologicaly different leukocyte proteins that cause cartilage resorption, lymphocyte activation and fever. J. Exp. Med. 162, 1208-1222

Sodek J., Ganss B., McKee M.D., 2000. Osteopontin Crit. Rev. Biol. Med. 31, 279-303

Tuo W., Harney J.P., Bazer F.W., 1996. Development regulated expression of interleukin-1 $\beta$ by periimplantation conceptus in swine. J. Reprod. Immunol. 31, 185-198

Vogiagis D., Salamonsen L.A., 1999. The role of leukaemia inhibitory factor in the establishment of pregnancy. J. Endocrinol. 160, 181-190

Vonnahme K.A., Fernando S.C., Ross J.W., Ashworth M.D., DeSilva U., Malayer J.R., Geisert R.D., 2004. Porcine endometrial expression of kininogen, factor XII, and plasma kallikrein in cyclic and pregnant gilts. Biol. Reprod. 70, 132-138

Wisniewski H., Hua J., Poppers D.M., Naime D., Vilcek J., Cronstein B.N., 1996. TNF/Il-1 inducible protein TSG- 6 potentiates plasmin inhibition by inter- $\alpha$-inhibitor and exerts a strong anti-inflammatory action. J. Immunol. 156, 1609-1610

Wuttke W., Spiess S., Knoke I., Pitzel L., Leonhard S., Jarry H., 1998. Synergistic effects of prostaglandins $\mathrm{F}_{2 \alpha}$ and tumor necrosis factor to induce luteolysis in the pig. Biol. Reprod. 58, $1310-1315$ 


\section{CYTOKINES AND ADHESION MOLECULES IN EARLY PREGNANT PIGS}

\section{STRESZCZENIE}

\section{Rola cytokin i cząsteczek adhezyjnych w matczynym rozpoznaniu ciąży u świń}

Matczyne rozpoznanie ciąży i skuteczny jej przebieg warunkowane jest przez wiele interakcji między zarodkiem a macicą. Uświni, głównym sygnałem zarodkowym umożliwiającym organizmowi matki rozpoznanie ciąży są estrogeny, których synteza i wydzielanie nasila się około11-go dnia ciąży. Zarówno zarodki jak i endometrium macicy wytwarzają wiele innych substancji sygnałowych, które biorą udział we wspomnianych oddziaływaniach miedzy zarodkiem a endometrium macicy w okresie okołoimplantacyjnym. Wiele spośród nich przypomina procesy zapalne, dlatego też towarzyszy im wzmożona synteza interleukin (IL-1 $\beta$, IL-6), a także innych cytokin (LIF, TNF $\alpha$ ). $\mathrm{W}$ trakcie gwałtownych zmian morfologicznych zarodka, tj. przekształcania się z formy sferycznej w nitkowatą, pojawia się ekspresja LIF (leukaemia inhibitory factor), który oddziaływuje na rozwój zarodka. Ponadto, na etapie implantacji u świni stwierdza się wzrost aktywności antywirusowej, której towarzyszy wzmożona synteza interferonów. Implantacja prowadzi do zagnieżdżenia się zarodka w endometrium macicy i regulowana jest głównie przez integryny, jednakże biorą w niej udział także inne cząsteczki powierzchniowe, takie jak Muc-1, Muc-4 czy osteoponina.

W związku ze wzrastającym zainteresowaniem badaniami nad rolą cytokin i cząsteczek adhezyjnych w procesach prowadzących do matczynego rozpoznania i ukonstytuowania ciąży, pojawia się potrzeba podsumowania obecnego stanu wiedzy na temat ich udziału w mechanizmach umożliwiających rozpoznanie i skuteczny przebieg ciąży u świni. Niniejsze opracowanie przyczynić się może do głębszego zrozumienia procesów zachodzących w okresie okołoimplantacyjnym u świni. 